\title{
- FEDERAL BRIDGE LEGISLATION AND THE CONSTITUTION
}

\section{PAXTON BLAIR}

Twenty-one years ago was the last occasion on which Congress enacted a comprehensive regulatory act ${ }^{1}$ on the subject of bridges, which, mirabile dictu, it has not yet found itself under the necessity of amplifying, recasting, or amending in any way. The detractors of our national legislature have often accused it of meaning one thing and accomplishing another. ${ }^{2}$ But here, at any rate, Congress expressed itself well, for it was not until the very recent decision of Newarl $v$. Central R. R. of New Jersey, ${ }^{3}$ that there occurred any suggestion from the bench of any doubt as to the intent of Congress in passing the Bridge Act of 1906. Even this suggestion merely took the form of the adoption of such a ratio decidendi as would render it unnecessary to pass upon the question whether Congress intended, in authorizing, by special act, a bridge over navigable waters wholly within one state, to dispense with state assent to the construction of the bridge. ${ }^{4}$ The court likewise refrained from deciding whether Congress could constitutionally dispense with state assent in such cases.

It is submitted that behind the court's dubitat lies a constitutional question of no mean profundity; and that a full analysis of the subject calls for inquiry into: (1) the normal source of power to construct a bridge over navigable waters wholly within one state; (2) congressional policy in bridge legislation prior to the Act of 1906 ; (3) the scope of the Bridge Act of 1906 ; (4) the sufficiency of existing federal statutes to effect a supersession of state legislation on the subject of bridges; and (5) the residue of unexerted congressional power.

I. THE STATE AS THE NORMAL SOURCE OF POWER TO BUILD BRIDGES

It is clear, upon the authorities, that the normal source of power to construct a bridge over navigable waters is in the state itself.

The most recent, as well as the most profound, discussion of this subject by the Supreme Court is found in the case of International Bridge Co. v. New York.5 The facts of the case are somewhat complicated and a rather full statement is indispensa-

134 Stat. 84, (1906) U. S. Comp. Stat. (1916) § 9961, U. S. C., Tit. 33, $\S 491$.

2 See, e. g., editorial in Boston Transcript, Jan. 16, 1917.

3267 U. S. 377,45 Sup. Ct. 328 (1925); discussed infra note 65.

4267 U. S. at 384,45 Sup. Ct. at 330 . The statute concerned was 41 Stat. 277 (1919).

5 254 U. S. 126, 41 Sup. Ct. 56 (1920). 
ble to a proper perception of the relative state and federal powers in the premises. The International Bridge Company was incorported by a special act ${ }^{\circ}$ for the purpose of erecting across the Niagara River at Buffalo a bridge for the use of persons on foot as well as of vehicles and trains. A special act of Congress ${ }^{3}$ approved the bridge preliminarily and a later statute, ${ }^{3}$ passed upon its completion, declared the bridge "to be a lawful structure, and an established post route for the mail of the United States." In 1899 the bridge was rebuilt without roadways and footpaths, pursuant to plans approved by the Secretary of War, but not by the state authorities. The rebuilding was completed in the year 1901. In 1907 the Secretary of War gave notice to the cornpany that the bridge obstructed navigation and required changes. The bridge was again reconstructed under the direction of the Secretary of War, without roadways and footpaths. The consent of the state authorities was, on this occasion also, neither sought nor obtained. The adoption of legislation ${ }^{3}$ to compel the restoration of the roadways and footpaths precipitated the suit in question, for the bridge company took the view that the action of the Secretary of War withdrew the bridge permanently from state control. In this it was unsuccessful, and the adverse view of the state courts ${ }^{10}$ was upheld in the Supreme Court.

The Supreme Court said: ${ }^{11}$

- "The part of the structure with which we are concerned is within the territorial jurisdiction of the State of New York. . . . The State was the source of every title to that land and, apart from the special purposes to which it might be destined, of every right to use it. Any structure upon it considered merely as a structure is erected by the authority of New York. The nature and qualifications of ownership are decided by the State and although certain supervening uses consistent with those qualifications cannot be interfered with by the State, still the foundation of a right to use the land at all must be laid by state law. Not only the existence of the Company but its right to build upon New York land came from New York

\footnotetext{
${ }^{6} \mathrm{~N}$. Y. Laws 1857 , c. 753 . A Canadian corporation was concurrently formed under authority of the Dominion govcrnment. Can. Stat., 20 Vict. c. 227 . The two corporations were consolidated under N. Y. Laws 1869, e. 550.

716 Stat. 173 (1870).

s 18 Stat. 275 (1874).

9 N. Y. Laws 1915 , c. 666 .

10 People v. Int'l Bridge Co., 223 N. Y. 187, 119 N. E. 351 (1918), affirming 179 App. Div. 950, 165 N. Y. Supp. 1104 (1917).

11254 U. S. at 132, 41 Sup. Ct. at 58. The court went on to xefor to certain general legislation on bridges passed in 1899 (30 Stat. 1151, U. S. Comp. Stat. (1916) \$ 9971) and said, at 133, 41 Sup. Ct. at 59: "The act does not make Congress the source of the right to build but assumes that the right comes from another source, that is, the State. It merely subjects the right supposed to have been obtained from there to the further condition of getting from Congress consent to action upon the grant."
} 
"From an early date the State has been recognized as the source of authority in the absence of action by Congress. ${ }^{12}$... And this Court has been slow to interpret such action as intended to exclude the source of rights from all power in the premises."

The effect of the decision is to declare that the states are the normal source of power to construct bridges and, save for the exceptional occurrence of positive action by Congress granting original and plenary power to particular grantees, ${ }^{13}$ they are the only source..$^{14}$

The decision is logical, and is supported by authority. ${ }^{15}$ But granting that the states are the normal source of power to authorize bridges, to what inherent sovereign right must we look for the ultimate source of that power itself, and are there limits to the exercise of that power?

The ultimate source of the power is the states' ownership of submerged lands. "The shores of navigable waters, and the

12 Citing Willson v. Blackbird Creek Marsh Co., 2 Pet. 245 (U. S. 1829); Escanaba Co. v. Chicago, 107 U. S. 678, 2 Sup. Ct. 185 (1883).

${ }^{13}$ See, for instance, the Act of July 11, 1890 (26 Stat. 268) incorporating the North River Bridge Co. The act was held constitutional in Luxton v. North River Bridge Co., 153 U. S. 525, 14 Sup. Ct. 891 (1894). See also cases cited infra note 75 .

14 It is reasonable to argue that congressional legislation not amounting to an original and plenary grant of power has not the effect of annulling . state legislation on the subject of bridges. This point is developed infra sub-head IV.

15 Lake Shore \& M. S. Ry. v. Ohio, 165 U. S. 365, 368, 17 Sup. Ct. 357, 358 (1897) ; City of Beaumont v. Texas \& N. O. R. R., 296 Fed. 523, 526 (E. D. Tex. 1924). And see 40 Cong. REc. 1717, quoted infra note 44.

In Kaw Valley Drainage Dist. v. Missouri Pacific Ry., 111 Kan. 183, 207 Pac. 218 (1922) the court refused to enjoin the reconstruction of a certain bridge on plans approved both by the state and by the War Department. The court viewed the plaintiff's conduct as captious, and quoted in full as an appendix to its opinion a "Memorandum for the Secretary of War" wherein was set forth the advice the Secretary acted on in issuing, over the protests of this plaintiff, his approval of the bridge plans in question. The memorandum is dated Feb. 18, 1922, and is signed by J. A. Hull, Acting Judge-Advocate General, and by J. M. Wainwright, Assistant Secretary of War. After citing and commenting on several cases, tho memorandum states, at 192, 207 Pac. at 223: "This comment seems necessary because of the great weight which complainants appear to attach to the instrument whose revocation they seek and which is referred to in several places in their brief as a 'permit.' The fact is that without tho requisite state authority it is ineffectual. It is true that it is not the practice of the War Department to issue instruments of approval in cases of this nature unless there is a showing of state authority for the work, and such a showing appears in the present case; but the action of the War Department has, of course, no binding effect upon the state, whose powor in the matter is plenary and will not be interfered with by the federal government unless it come in conflict with the power vested in the federal government with respect to the protection, preservation and improvement of navigation." And see, to substantially the same effect, Judge Baldwin's 
soils under them, were not granted by the Constitution to the United States, but were reserved to the states respectively." 10 The capacity of this ownership of submerged lands to accomplish control over bridges was well expressed in an analogous case supporting a state's right to compel an interstate railroad to abolish grade crossings. ${ }^{17}$ The court said : ${ }^{18}$

"To engage in interstate commerce the railload must get on to the land and to get on to it must comply with the conditions imposed by the State for the safety of its citizens."

It is clear, however, that this ownership is subject to certain paramount rights in the federal government. ${ }^{19}$ The ultimate source of the federal power is the commerce clause since "commerce includes navigation." so $\mathrm{Or}$, to employ the fuller statement of Mr. Justice Day, in Stone v. Southern Illinois Bridge Co.: ${ }^{21}$

"Federal control of bridges constructed over navigable waters is maintained because of the right to prevent obstructions to navigation and preserve such public highways as rivers for free and unobstructed use in the interest of commerce." nn

It follows that the power of the state to authorize the erection of bridges, and hence the power to forbid the erection of particu-

concurring opinion in Lane v. Smith, 71 Conn. 65, 70-71, 41 Atl. 18, 20 (1898).

16 Pollard's Lessee v. Hagan, 3 How. 212, 230 (U. S. 1845). And sea Martin v. Waddell, 16 Pet. 367,410 (U. S. 1842); Van Brcellin v. Tennessee, 117 U. S. 151, 168, 6 Sup. Ct. 670, 679 (1SS6); Alabama Power Co. v. Gulf Power Co., 283 Fed. 606, 617 (II. D. Ala. 1922).

17 Erie R. R. v. Bd. of Pub. Util. Comm. of New Jersey, 251 U. S. 891, 41 Sup. Ct. 169 (1921). And see R. R. Comm. of Californin v. Sonthern Pacific Co., 264 U. S. 331, 341, 44 Sup. Ct. 376, 377 (1924). The existence in the states of a right to compel the alteration, to improve navigation, of a bridge used by interstate trains was recognized in Lake Shore $\&$ MI. S. Ry. v. Ohio, supra note 15, at 369, 17 Sup. Ct. at 358, affirming 51 Ohio St. 619 (1894). The bridge, however, was not built under federal but under state authorization.

18 At 411, 41 Sup. Ct. at 171.

19 The general language of Pollard's Lessee v. Hagan and the other cases cited supra note 16, must be read in the light of the opinion in Gibson v. United States, 166 U. S. 269, 271-272, 17 Sup. Ct. 578, 579 (1897) where the court said: "All navigable waters are under the control of the United States for the purpose of regulating and improving navigation, and although the title to the shore and submerged soil is in the various States and individual owners under them, it is always subject to the servitude in respect of navigation created in favor of the Federal government by the Constitution." See also the cases cited infra note 90.

${ }^{20}$ Gilman v. Philadelphia, 3 Wall. 713, 723 (U. S. 1865). And see Scranton v. Wheeler, 57 Fed. 803,813 (C. C. A. 6th, 1893), affd 179 U. S. 141, 21 Sup. Ct. 48 (1900).

21206 U. S. 267, 27 Sup. Ct. 615 (1907).

22 At 274, 27 Sup. Ct. at 618. 
lar bridges, is limited by the power of Congress under the commerce clauise.

There is thus presented for consideration the question of how far Congress has, up to the present time, covered the field, and to what extent state powers have been put to sleep.

\section{CONGRESSIONAL POLICY IN BRIDGE LEGISLATION PRIOR TO 1906}

It is obvious that Congress, deriving its power in the premises from the commerce clause, could make the furtherance of landborne commerce its goal in bridge legislation, as well as aiding navigation or water-borne commerce. ${ }^{23}$ Hence it is rather startling to note that the trend of legislation in Congress since 1880 on the subject of bridges over navigable waters shows consistently the aiding of navigation as the dominant purpose in the mind of the legislature; the development of land commerce has been either subordinated to navigation or, more frequently, ignored altogether.

All congressional bridge statutes of a general nature, prior to 1906, occur in Rivers and Harbors Acts.

The Secretary of War was entrusted with the protection of navigable waters as early as $1880 .{ }^{24}$ His duties and powers under the act passed in that year were confined to the removal of "any sunken vessel or watercraft," but were extended in $1884{ }^{25}$ "to any railroad or other bridge [believed to be] an obstruction to the free navigation of" the navigable waters of the United States. His powers were slightly elaborated and fortified by penal provisions in $1888,{ }^{26}$ and while the act of $1890^{27}$ curtailed his powers by specifying that only "unreasonable" obstructions were aimed at and by requiring notice to be given to interested parties before abatement, yet it amplified his powers greatly by providing that: ${ }^{28}$

". . . it shall not be lawful hereafter to commence the construction of any bridge, bridge-draw, bridge piers and abutments, causeway or other works over or in any port, road, roadstead, haven, harbor, navigable river, or navigable waters of the United States, under any act of the legislative assembly of any State, until the location and plan of such bridge or other works have been submitted to and approved by the Secretary of War, or to excavate or fill, or in any manner to alter or modi-

${ }^{23}$ It is nevertheless true that in defining admiralty jurisdiction bridges, generically, are treated as aids to commerce and not as aids to navigation. Cleveland Terminal \& Valley R. R. v. Cleveland Steamship Co., 208 U. S. 316, 28 Sup. Ct. 414 (1908); The Kearney, 14 Fed. (2d) 949 (C. C. A. 3d, 1926). And see The Blackheath, 195 U. S. 361, 25 Sup. Ct. 46 (1904); The Raithmoor, 241 U. S. 166, 36 Sup. Ct. 514 (1916).

2421 Stat. 180, 187.

2523 Stat. 133, 148, U. S. Comp. Stat. (1916) § 9969.

2625 Stat. 400, 424-425.

2726 Stat. 426, 453.

${ }^{28} 26$ Stat. $454, \S 7$. As to whether the action of the Secretary of War is 
fy the course, location, condition, or capacity of the channel of said navigable water of the United States, unless approved and authorized by the Secretary of War. . . ."

Then follow certain provisos, one of which is to the effect that the act shall not be construed to authorize the construction of a bridge under state authorization alone ${ }^{23}$ where the bridge is over a "navigable water not wholly within the limits of such State." "30

Passing over the act of $1892^{31}$ as contributing no changes of substance, we come to the act of 1899.32 By this statute, the prohibition against the construction of a bridge over navigable waters was made absolute

"until the consent of Congress to the building of such structures shall have been obtained and until the plans for the same shall have been submitted to and approved by the Chief of Engineers and by the Secretary of War..."

Then follows a proviso whose chief departure from that in the two preceding enactments lies in the substitution of an affirmative for a double negative and in other changes lessening ambiguity. The proviso in the 1899 Act reads:

"Provided, That such structures may be built under the authority of the legislature of a State across rivers and other waterways the navigable portions of which lie wholly within the limits of a single State, provided the location and plans thereof are submitted to and approved by the Chief of Engineers and by the Secretary of War before construction is commenced ...."

The state of the law upon the taking effect of the Act of 1899 was the subject of exhaustive examination in Cummings v. Chicago. $^{33}$ In this case, the plaintiff-appellant having secured leave of the Secretary of War to construct a pier in a navigable stream, sought to enjoin the City of Chicago from interfering with the prosecution of the work. The consent of neither the City of Chicago nor the State of Illinois had been secured. The Circuit Court denied relief and the Supreme Court affirmed this decision. Mr. Justice Harlan stated the questions before the court thus: ${ }^{34}$

subject to judicial review, see Monongahela Bridge Co. v. United States, 216 U. S. 177, 195, 30 Sup. Ct. 356, 361 (1910).

29 That is, without express legislation by Congress on the subject in addition to the approval of the plans by the Secretary of War. See Lalie Shore \& II. S. Ry. v. Ohio, supra note 15, at 369,17 Sup. Ct. at 358.

3026 Stat. $454, \S 7$.

3127 Stat. 88, 110.

3230 Stat. 1121, 1151, §§ 9, 10, U. S. Comp. Stat. (1916) $\S \S 9971,9972$, U. S. C., Tit. $33, \$ \S 401,403$.

33188 U. S. 410,23 Sup. Ct. 472 (1903).

34 At 428, 23 Sup. Ct. at 476. 
"Did Congress, in the execution of its power under the Constitution to regulate interstate commerce, intend by the legislation in question to supersede, for every purpose, the authority of Illinois over the erection of structures in navigable waters wholly within its limits? Did it intend to declare that the wishes of Illinois in respect of structures to be erected in such waters need not be regarded, and that the assent of the Secretary of War, proceeding under the above acts of Congress, was alone sufficient to authorize such structures"?

The answer given to the questions was an emphatic negative, the holding being that section 10 of the River and Harbor Act of $1899^{35}$

".... is not so worded as to compel the conclusion that Congress intended, by that section, to ignore altogether the wishes of Illinois in respect of structures in navigable waters that are wholly within its limits." 36

The Court went on to say that,

"... we will not at this time make any declaration of opinion as to the full scope of this power or as to the extent to which Congress may go in the matter of the erection, or authorizing the erection, of docks and like structures in navigable waters that are entirely within the territorial limits of the several States. Whether Congress may, against or without the expressed will of a State, give affirmative authority to private parties to erect structures in such waters, it is not necessary in this case to decide. It is only necessary to say that the act of 1899 does not manifest the purpose of Congress to go to that extent under the power to regulate foreign and interstate commerce and thereby to supersede the original authority of the States. The effect of that act, reasonably interpreted, is to make the erection of a structure in a navigable river, within the limits of a State, depend upon the concurrent or joint assent of both the National Government and the state government. The Secretary of War, acting under the authority conferred by Congress, may assent to the erection by private parties of such a structure. Without such assent the structure cannot be erected by them. But under existing legislation they must, before proceeding under such an authority, obtain also the assent of the State acting by its constituted agencies." 37

\section{THE SCOPE OF THE BRIDGE ACT OF $1906^{\text {ss }}$}

The outstanding feature of this act is the omission of Congress to state in it when the congressional consent to a bridge is necessary to legalize it. If the bridge is over navigable waters wholly

\footnotetext{
35 Supra note 32.

36188 U. S. at 430,23 Sup. Ct. at 477.

37 At $430-431,23$ Sup. Ct. at 477 . See also Montgomery v. Portland, 190 U. S. 89, 106, 23 Sup. Ct. 735, 737 (1903); Gring v. Ives, 222 U. S. 365, 32 Sup. Ct. 167 (1912).

38 Supra note 1.
} 
within one state, express legislation from Congress is as unnecessary after 1906 as before. ${ }^{39}$ Congress, in such cases, exercises its supervisory control through the device of compulsory submission of the plans to the Secretary of War. ${ }^{40}$ It had been the practice prior to 1906 in the case of bridges over navigable waters not wholly within one state to supplement state authorization ${ }^{41}$ by a special act of Congress. The strongest motivating force behind the legislature, therefore, was the reduction of the length of the various special acts required in the case of each bridge over navigable waters not wholly within one state. This is apparent from the committee report ss on the bill made to the House of Representatives. The report said:

"The purpose of the bill is to establish uniform regulations in regard to the construction and operation of bridges over navigable waters when hereafter authorized by Congress. A further purpose is to prevent the cumbering up of the statute bools by repeating in each bridge bill the same provisions, and also to shorten the time for considering and reading bridge bills in the two Houses of Congress." 43

${ }^{39}$ In re Westlake Avenue, Seattle, 66 Wash. 277, 285, 119 Pac. 798, 802 (1911).

so Chicago Transportation Co. v. Pennsylvania Co., 246 Fed. 190 (N. D. IIl. 1917). In this case, the libelants sued for damages to a sailing vesial. The bridge was built in the winter of 1913-1914, and the libelants alleged it unreasonably obstructed navigation in that it offered a clearance of only 120 feet above water, so that the masts of the libelants' vessel were brolien in passing under it. The respondents pleaded as a defense (1) that the bridge was authorized by the Secretary of War under the Act of 1890; and in case this should be held insuficient, they pleaded (2) that they had secured the state's consent to the bridge as well. The court, following Lake Shore \& MI. S. Ry. v. Ohio, supia note 15, held the federal permit by itself insufficient, but held the possession of permits from both governments a complete defense, saying, at 192: "The Chicago river is wholly within the state of Illinois. . . . The state has the power to authorize the construction of the bridge; the Secretary of War had the power to permit or refuse to permit the bridge to be built, his discretion being controlled by the effect the proposed bridge would have upon commerce and navigation. It follows that two permits are essential to the construction of such bridges, one by the state, or its authorized agent, and the other by the United States government through the Secretary of War. The respondents have secured both. The bridge was therefore duly authorized, and was a lawful structure."

41 As was pointed out supra notes 29,30 , the act of 1858 in effect declared state authorization inadequate in such cases. The more esplicit provisions of the same purport in the act of 1899 vere referred to supra at page 814 .

42 H. R. ReP. No. 182, 59th Cong. 1st Sess., at 1.

43 The report went on to say: "Under the practice now in force the Committee on Interstate and Foreign Commerce of the House and the Committee on Commerce of the Senate, having jurisdiction of bridge bills, require the insertion in each bill of certain provisions. These provisions make the bill long, take up the time of the two Houses of Congress in the reading of them, and add to the length of the laws when enacted. 
Congressman Mann, of Illinois, a member of the committee which signed the report, gave a further elucidation of the purpose of the bill on the floor of the House. ${ }^{44}$

It is significant that in the typical special bridge act, Congress gives not its "consent" but its "authority." 45

Another feature of the Act of 1906 is its continuation of the policy of the Act of 1899 in making aid to navigation its dominant purpose rather than aid to railroads engaged in interstate

"The present bill gathers these provisions into one general law, so that hereafter a bill to authorize the construction of a bridge may be in form similar to the following:

"'A Bill to authorize John Doe Railroad Company to construct a bridgo across the Richard Roe River, at or near Black Acre.

" 'Be it enacted by the Senate and House of Representatives of the United States of America in Congress assembled, That the John Doe Railroad Company, its successors and assigns, be, and they are hereby, authorized to construct, maintain and operate a bridge across the Richard Roe River, at or near Black Acre, in the State of —_, in accordance with provisions of the act entitled "An act to regulate the construction of bridges over navigable waters, approved —_, nineteen hundred and -."”

The suggestion has recently been made that Congress be relieved altogether from the consideration of bridge bills, by some device framed along the lines of the English Provisional Order system. LUCE, Congress-AN ExplaANation (1926) 146.

14 "Mr. Garrett: To what extent does the power of the Secretary of War now go on streams wholly within the limits of the State? That is, what is the extent of the power of the respective legislatures of the States and the extent of the power of the Secretary of War in regard to the construction of bridges across streams?

"Mr. Mann: As I said before, the right, so far as the Government is concerned, is a mere license, a right to prevent the construction of bridges, and under the existing statute the Secretary of War is authorized, so far as the Government is concerned, to give consent to the erection of bridges over any stream wholly within the limits of a State. Of course, the power to construct the bridges must be derived from the State itself, but the Government does not interfere with the right to do this. In other words, the power of the Government is not exercised to regulate interstate com. merce, but to prevent the interference with navigation and navigable streams, and the Government merely waives its right in behalf of persons who must obtain their authority elsewhere." 40 CoNG. REC. 1717.

45 See the form given supra note 43 . The opening words of the Act of 1906, supra note 1, are: "Be it enacted . . . That when, hereafter, anthority is granted by Congress to any persons to construct and maintain a bridge across or over any of the navigable waters of the United States . . " [our italics].

The difference between "consent" and "authority" has been moro than once adverted to. See Willamette Iron Bridge Co. v. Hatch, 125 U. S. 1, 13, 8 Sup. Ct. 811, 817 (1888); Blair v. Chicago, 201 U. S. 400, 457, 26 Sup. Ct. 427, 439 (1906) ; People v. Hudson River Connecting R. R. Corp., 228 N. Y. $203,221,126$ N. E. 801,807 (1920), certiorari denied, 254 U. S. 631, 41 Sup. Ct. 7 (1920). As to whether, on the other hand, under some circumstances the two words may assume identity of meaning, see Hagerla v. Mississippi River Power Co., 202 Fed. 776, 784 (S. D. Ia. 1913). 
commerce. This has an important bearing on the question of the supersession of state laws by federal bridge legislation. ${ }^{40}$

The Supreme Court has not been forward in citing the Act of 1906 in litigation concerning bridges, booms, wharves, etc., erected under state authority, which has reached it since the effective date of the act.: This is probably due to the failure, already adverted to, of the Act to include criteria for ascertaining whether or not in a particular case state legislation is allowed to retain vitality. On the other hand, the Act of 1906 was discussed by the Supreme Court of Washington in the case of In re Westlake Avenue, and the following conclusion reached: ${ }^{49}$

"From authorities cited, and the history of Congressional legislation, it is manifest that the national policy as to waters lying wholly within a state has at all times been that the state, or its authorized representatives, shall, in the first instance, select locations and adopt plans for bridges, but that prior to actual construction, and for the protection of navigation, such locations and plans shall be approved by the secretary of war:"

And in Pedrick v. Raleigh \& Panlico Sound Railioad, ${ }^{50}$ the Supreme Court of North Carolina said: st

"It may be proper to say that we do not concur in the view pressed by defendant, that the decision of the Secretary of War permitting the location of the bridge is conclusive. The control of its navigable waters is with the State, the authority of the General Government being only cumulative protection from an interference with commerce."

48 See infra sub-head IV.

${ }^{47}$ In Union Bridge Co. v. United States, 204 U. S. 364, 367, 27 Sup. Ct. 367,368 (1907) MIr. Justice Harlan, in his statement of the case, set forth the history of legislation on navigable waters (the case beford the court being an information charging wilful failure to alter a bridge found by the Secretary of War to be an unreasonable obstruction to navigation) and said: "Finally, we have the act of March 28d, 1006, 34 Stat. 84, c. $1130, \S \S 4,5$, which covers the same ground as the act of 1899 under which the present information was filed."

Other Supreme Court decisions subsequent to 1906 are North Shore Boom Co. v. Nicomen Boom Co., 212 U. S. 40G, 29 Sup. Ct. 355 (1909), act not cited; Gring v. Ives, supra note 37, act not cited; International Bridge Co. v. New York, supra note 5, act not cited; Port of Seattle v. Oregon \& W. R. R., 255 U. S. 56, 41 Sup. Ct. 237 (1921), act not cited; Newark v. Central R. R. of New Jersey, supra note 3, act cited but regarded as not germane to the decision.

18 Supra note 39.

49 At 287-288, 119 Pac. at 803.

so 143 N. C. 485 , 55 S. E. 877 (1906).

51 At 511, 55 S. E. at 886. See also Minnesota Canal Co. v. Pratt, 101 Minn. 197, 224, 112 N. W. 395, 402 (1907) ; Gulf, C. \& S. F. Ry. v. Meadows, 56 Tex. Civ. App. 131, 136-137, 120 S. W. 521, 524 (1909); Kaw Valley 


\section{THE SUPERSESSION OF STATE LEGISLATION BY FEDERAL BRIDGE STATUTES}

We have seen that in the case of bridges over navigable waters wholly within one state the federal laws go no further than to require the approval of the Secretary of War of the plans for the bridge, the permission to build it having been previously secured from the state. Hence, in the case of such bridges, no contention of any supersession of state laws by the mere license or approval issued by the Secretary of War could possibly have any foundation. And such contentions whenever made have been summarily dismissed. ${ }^{52}$

A more difficult question arises where the bridge is over navigable waters not wholly within one state. As to such bridges, Congress has always made it a practice to authorize them by special legislation, the Bridge Act of 1906 being designed to facilitate and abbreviate the special legislation to be adopted in each case. ${ }^{53}$ The same question arises where Congress has, even though the bridge is over navigable waters wholly within one state, seen fit to authorize it by special act in the typical form..$^{64}$

Has such a special bridge act the effect of superseding state laws conditioning the right to build bridges?

The general principle concerning supersession, to be induced

Drainage Dist. v. Missouri Pacific Ry., 99 Kan. 188, 207-208, 161 Pac. 937, 946 (1916) ; People v. Metropolitan West Side Elevated Ry., 285 Ill. 246, 257, 120 N. E. 748,752 (1918), writ of error dismissed for want of jurisdiction, 252 U. S. 573, 40 Sup. Ct. 395 (1920).

A somewhat different view, however, was entertained by the court in Milwaukee-Western Fuel Co. v. Milwaukee, 152 Wis. 247, 139 N. W. 540 (1913). Here the plaintiff sought damages caused by the obstruction to navigation effected by a bridge, and an injunction against its continuance. The bridge plans had not received the approval of the Milwaukee city council (which under the law of the state had jurisdiction over such matters), but the city itself was the builder. The plans, however, had the approval of the Secretary of War. The court held such approval conclusive to tha effect that navigation was not obstructed; and since proof of obstruction wos part of the plaintiff's case, the consequence of the court's holding was a dismissal of the complaint. To substantially the same effect is Frost $v$. Washington County R. R., 96 Me. 76, 51 Atl. 806 (1901).

52 Cobb $\nabla$. Commissioners of Lincoln Park, 202 Ill. 427, 438-439, 67 N. T. 5 , 9 (1903) ; Attorney-General v. Hudson County Water Co., 76 N. J. Eq. 543, 559, 76 Atl. 560, 566 (1909); Hubbard v. Fort, 188 Fed. 987, 999 (C. C. N. J. 1911). And see the cases cited supra notes 5, 33, 37, 51.

${ }^{53}$ See the form set forth supra note 43.

54 It will be remembered that the Bridge Act of 1906 does not indicate that Congress will resort to special acts only where the bridge is not over navigable waters wholly within one state. See supra note 45. The power of Congress is the same whether the waters to be bridged are or are not wholly within one state. Decker v. Baltimore \& N. Y. R. R., 30 Fed. 723, 724 (C. C. S. D. N. Y. 1887) ; Rhea v. Newport N. \& M. V. R. R., 50 Fed. 16, 21 (C. C. Ky. 1892); Minnesota Canal \& Power Co. v. Pratt, supra note 51 . 
from the numerous cases on the subject, is that an intention on the part of Congress to supersede or suspend, through enact. ments under the commerce clause, the exercise of the reserved powers of a state should not be inferred "unless, and except so far as, its purpose to do so is clearly manifested." $s$ There is, in other words, no necessity of implying such an intention "unless the act of Congress fairly interpreted is in actual conflict with the law of the State."

Nothwithstanding an observation made at circuit by Mrr. Justice Bradley to the effect that "It is commerce, and not navigation, which is the great object of constitutional care," $\mathrm{cr}$ the fact remains that the bridge acts, including that of 1906, show aid to navigation as their dominant purpose..$^{5 s}$ This being so, it is difficult to imply in such acts an intention to supersede state laws which, too, have as their purpose aid to navigation. It happens, however, that the only decisions involving bridges erected under the sanction of special acts have held otherwise. In one of these, Stockton v. Baltimore \& New York $R . R ., 50$ is manifest an inclination on the part of the court to disregard the intcat of Congress in the acts then in force and to focus attention upon the power of Congress. Had the complainant's solicitor not tried to prove too much, he might have succeeded in his efforts to have the state's concurrent power of bridge authorization upheld-in the absence, at any rate, of a more unequivocal expression of an intent to dispense with it than was there present. In another case, People v. Hudson River Connceting R. R. Corporation, ${ }^{\mathrm{c}}$ the state's attorney-general argued forcibly to the effect that an intent to supersede had not been made out. The decision went against him, but again the court's vision was obscured by fear

55 Mlinois Central R. R. v. Public Utilities Comm., 215 U. S. 498, 510, 38 Sup. Ct. 170, 176 (1918).

56 Savage v. Jones, 225 U. S. 501, 533, 32 Sup. Ct. 715, 726 (1912). Anơ see North Shore Boom Co. v. Nicomen Boom Co., supra note 17 ; Missouri, K. \& T. Ry. v. Haber, 169 U. S. 613, 18 Sup. Ct. $48 S$ (1S9S); Hagen v. City of Richmond, 104 Va. 723, 729, 52 S. E. 385, 387 (1905).

57 Stockton v. Baltimore \& N. Y. R. R., 32 Fed. 9, 20 (C. C. N. J. 1837), appeal dismissed without argument, 140 U. S. 699, 11 Sup. Ct. $102 S$ (1801). It used to be the accepted view that the right of navigation is one "to which all others are subservient." Lorman v. Benson, 8 Miich. 18, as (1860). Though this was approved in Scranton v. Wheeler, 170 U. S. 141, 163-4, 21 Sup. Ct. 48, 57 (1900) yet today land-borne commeree is unquestionably entitled to more consideration than water-borne commerce, a result whose eventual realization was foreseen by the Suprome Court in California v. Pacific Railroad, 127 U. S. 1, 39, S Sup. Ct. 1073, 10 So (188s) and in Luxton v. North River Bridge Co., 153 U. S. 525, 534, 14 Sup. Ct. 891,894 (1894).

ss See supra page 813.

59 Supra note 57. The bridge was an interstate bridge authorized by 24 Stat. 78 (1886). For further references to this case see infro notes $70-85$.

${ }^{60}$ Supra note 45. 
of the consequences of denying to Congress the power to effect a supersession. The decision is sustainable as a correct exposition of the obligation of contracts clause of the constitution. ${ }^{\text {at }}$ As an authority on state and federal control over navigable waters, an astute writer has pointed out excellent reasons why it merits scant respect. ${ }^{62}$ In Newark v. Central R. R. of New Jersey, ${ }^{63}$ the Circuit Court of Appeals made no pretense at inquiry into intent (although the briefs discussed both intent and power) and, falling into something akin to petitio principii, said: ${ }^{64}$

"If the consent of a state were necessary before a bridge could be built over navigable waters within its borders, the power of regulating commerce among the states and with foreign nations would reside in the states and not in Congress. In the case at bar, Congress has authorized the construction of the bridge notwithstanding the opposition of the state of New Jersey. Its power to do this was plenary and may not be interfered with by that state."

The Supreme Court affirmed on the ground that the state had consented to the bridge and that questions of congressional power or intent were not before it. ${ }^{65}$

61 As to the essential question in the case, the court said, at 224, 126 N. E. at 808: "Can the legislature of New York state interfere with the plenary power of Congress to authorize this bridge for interstate commorco by depriving the corporation, authorized and vested with a grant of franchise from Congress, of the power intra vires to avail itself of the franchise by subsequently imposing the penalty of the injunction and forfeituro of its charter for exercise of the franchise? The answer must be in tho negative." The only holding in this case is that the state had not effectivoly substituted its veto for its previously given consent. In the first place tho state was "not opposed to the construction of $a$ bridge at the location selected" (page 208). In the second place the state had affirmatively given consent to the construction of a bridge with more than one span at tho point in question [N. Y. Laws 1913 , c. 388-the franchise conferred by this Act not being subject to a reserved right to amend, alter or repeal); thereafter the bridge was authorized by Act of Congress (38 Stat. 308 (1914)] and plans were approved by the Secretary of War. It was only after such approval had occurred that the state attempted to withdraw its consent, but the withdrawal was by an act which was void as an impairment of the obligation of a contract.

62 Parsons, Public and Private Rights in the Foreshore (1922) 22 Cor.

L. REv. 706, 721.

03297 Fed. 77 (C. C. A. 3d, 1924).

64 At 82.

65 Supra note 3. Specifically, the court held that the consent given by the State of New Jersey in N. J. Laws 1860, c. 64, to the erection across Newark Bay of a two-track swing-draw bridge "expanded" to include and sanction the erection in 1923 of a four-track bridge with stone arches and a vertical lift draw. It had generally been supposed that state grants in derogation of the public's right of navigation were to be strictly construed and to be deemed disposed to "contract," if anything, rather than "expand" 
One of the strongest arguments for implying a supersession of state laws is the attainment of uniformity of commercial regulations. But the Constitution exacts a rule of construction favoring uniformity in those cases only "where such uniformity is practicable. Where, from the nature of the subject or the sphere of its operation the case is local and limited, special regulations adapted to the immediate locality could only have been contemplated." 6 Upon such subjects, and bridges would seem to be included among them, ${ }^{67}$ conglessional non-action does not mean the negation of state power but simply that "for the time being, and until Congress sees fit to act, they may be regulated by State authority." is Hence, we are thrown back upon the criteria already cited ${ }^{\circ}$ for the determination of the question of whether state legislation has been superseded or not, and the bases for inferring supersession are insufficient. It would be easy to insert either in the Act of 1906 or in each special act passed under it some such phrase as "the law of any State or the decision or order of any State authority to the contrary notwithstanding." "70 This raises the constitutionality of such a proviso.

V. THE RESIDUE OF UNEXERTED CONGRESSIONAL POWER

In Willamette Iron Eridge Co. v. Hatch,;1 the Circuit Court

with lapse of time. See, in this connection, the leading cases of Illinois Central R. R. v. Illinois, 146 U. S. $387,453,460,12$ Sup. Ct. 110, 118, 121 (1892) and Charles River Bridge v. Warren Bridge, 11 Pet. 420, 547-553 (U. S. 1837). See also Massachusetts v. New York, 271 U. S. 65, at 89, 46 Sup. Ct. 357, at 361, 635, 636 (1926); Louisville Bridge Co. v. United States, 242 U. S. 409, 417, 37 Sup. Ct. 158, 160 (1917); Arnold v. IIundy, 6 N. J. L. 1, 78 (1821); Townsend v. Brown, 24 N. J. L. 80,87 (1853); People v. New York \& S. I. Ferry Co., 68 N. Y. 71, 7G-77 (1877); MIilwaukee v. Gimbel Bros., 130 Wis. 31, 36, 110 N. W. 7, 9 (1906); (1920) 40 Harv. L. REv. 140.

${ }^{66}$ County of Mobile v. Kimball, 102 U. S. 691, 698 (1850); see Cardwell v. American Bridge Co., 113 U. S. 205, 210, 5 Sup. Ct. 423, 425 (1885). er Gilman v. Philadelphia, supra note 20, at 726; Rhea v. Newport N. \& M. V. R. R., loc. cit. supra note 54 .

as County of Mobile v. Kimball, supra note 66, at 699; see also Dover v. Portsmouth Bridge, 17 N. H. 200, 226 (1845).

69 Supra notes $55,56$.

70 See, e. g., Transportation Act, 1920, $\$ 407$ (6) (c), 41 Stat. 482, U. S. Comp. Stat. (1916) $\$ 8567$ (6) (c), U. S. C., Tit. 49 , $\$ 5$ (6) (c). In the act authorizing a bridge over the Ohio River connecting Steubenville, Ohio, with a point opposite in Virginia, Congress declared that either a named Ohio corporation or a named Virginia corporation might "complete, maintain and operate said road and bridge, . . . anything in ang law or laws of the above-named States to the contrary notwithstanding." 12 Stat. 569, at 570 (1862). It must be admitted, however, that in practice it is more frequent to find express provisions for state consent, zo that silence leads to the inference that state consent is dispensed with. See Stockton v. Baltimore \& N. Y. R. R., supra note 57, at 17.

71 Supra note 45 , reversing Wallamet Iron Bridge Co. v. Hatch, 19 Fed. 347 (C. C. D. Or. 1884). 
for the District of Oregon had enjoined the construction of a bridge on the ground that the bridge company had secured state authorization ${ }^{72}$ alone and not federal, and that such authorization was no authorization at all because the state laws had been superseded. All the complainant was able to show, however, was certain general provisions for the freedom of navigable waters in the Oregon Statehood Act ${ }^{73}$ and the appropriation and expenditure by Congress of certain sums for dredging the Willamette River.74 This, the court (reversing the court below) held, was not such a covering of the field as to effect a supersession of the state's power to authorize the bridge in question. But as to the power Congress might have exerted, the court said: ${ }^{75}$

"We do not doubt that Congress, if it saw fit, could thus assume the care of said streams, in the interest of foreign and interstate commerce; we only say that, in our opinion, it has not done so by the clause in question. And although, until Congress acts, the States have the plenary power supposed, yet, when Congress chooses to act, it is not concluded by anything that the States, or that individuals by its authority or acquiescence, have done, from assuming entire control of the matter, and abating any erections that may have been made, and preventing any others from being made, except in conformity with such regulations as it may impose. It is for this reason, namely, the ultimate (though yet unexerted) power of Congress over the whole subject matter, that the consent of Congress is so frequently asked to the erection of bridges over navigable streams. It might itself give original authority for the erection of such bridges when called for by the demands of interstate commerce by land; but, in many, perhaps the majority of cases, its assent only is aslred, and the primary authority is sought at the hands of the State."

In Stockton $v$. Baltimore \& New Yorl R. R., ${ }^{\text {To }}$ the court after giving, as has already been remarked, ${ }^{77}$ insufficient heed to congressional intent, proceeded to declare affirmatively that Congress possessed the power by virtue of the commerce clause to supersede and deprive of vitality all state legislation designed to

72 Or. Laws 1878, 55.

1311 Stat. 383 (1859).

1418 Stat. 242 (1875); 18 Stat. 460 (1875).

75125 U. S. at 12-13, 8 Sup. Ct. at 817. This doctrine was reaffirmed in Luxton v. North River Bridge Co., supra note 13, at 532, 14 Sup. Ct. at 893.

In Southern Pacific R. R. v. United States, 183 U. S. 519, 527, 22 Sup. Ct. 154, 157 (1902)* the court said: "It is well settled that Congress has power to grant to a corporation created by a State additional franchisesat least franchises of a similar nature." And see, to the same effect, Oregon Short Line \& Utah Northern Ry. v. Skottowe, 162 U. S. 490, 494, 16 Sup. Ct. 869, 870 (1896); People ex rel. Postal Telegraph-Cable Co. v. Tax Commissioners, 224 N. Y. 167, 176, 120 N. E. 192, 194 (1918); In re Control of Central Pacific R. R., 76 I. C. C. 508, 517-518 (1923).

${ }^{76}$ Supra note 57. The bridge was from Staten Island, N. Y., to a point in New Jersey and was authorized by a special act of Congress, 24 Stat. 78 (1886).

т7 Supra note 59. 
circumscribe with conditions the right to build bridges for use in interstate commerce. MIr. Justice Bradley, in a vigorous opinion, said: ${ }^{78}$

"Nor have we any doubt that, under the same power, the means of commercial communication by land as well as by water may be opened up by congress between different states, whenever it shall see fit to do so, either on failure of the states to provide such communication, or whenever, in the opinion of congress, increased facilities of communication ought to exist. Hitherto, it is true, the means of commercial communication have been supplied, either by nature in the navigable water's of the country, or by the states in the construction of roads, canals, and railroads, so that the functions of congress have not been largely called into exercise under this branch of its jurisdiction and power, except in the improvement of rivers and harbors, and the licensing of bridges across navigable streams. But this is no proof that its power does not extend to the whole subject in all its possible requirements. Indeed, it has been put forth in several notable instances, which stand as strong arguments of practical construction given to the constitution by the legislative department of the government."

By far the most interesting part of MIr. Justice Bradley's opinion is that disposing of the argument that Congress had no power to authorize the use, as a foundation for bridge piers, of submerged lands owned by the state without either securing the state's consent to such use of submerged lands, or else taling title thereto by condemnation. The argument probably made to him was that the commerce power must be exercised with due regard to the requirements of the Fifth Amendment; ${ }^{\circ 0}$ that a state is a "person" entitled to invoke the amendment; "s that a corporation "cannot acquire a right to property by [its] desire to use it in commerce among the States." si

But to this Mrr. Justice Bradley found several answers. In the first place, he pointed out that to make the erection of a bridge hinge on state consent to the use of necessary lands

78 At 16 . The court referred to the acts authorizing the Cumberland Road [2 Stat. 357 (1806)] and also to the Pacific Railroad Acts [12 Stat. 489 (1862) ; 13 Stat. 326 (1864) ].

79 MIonongahela Navigation Co. v. United Statcs, 148 U. S. 312, 236, 13 Sup. Ct. 622, 630 (1893) ; United States v. Cress, 243 U. S. 316, 326, 37 Sup. Ct. 380, 384 (1917).

so There is a dictum in Georgia v. Chattanooga, 264 U. S. 472, 481, 41 Sup. Ct. 369, 371 (1924) to the effect that a state is entitled to involie the Fourteenth Amendment to protect its property from uncompensated taling at the hands of another state; and a conviction that this was so rras evidently in the mind of the draftsman of the complaint in Massachusetts $v$. New York, supra note 65, at 67, 46 Sup. Ct. at 358.

81 Hudson County Water Co. v. MIcCarter, 209 U. S. 849, 357, 2 S Sup. Ct. 529, 531 (1908). 
"brings us to a reductio ad absurdum. It interposes an effectual barrier to the execution of a constitutional power vested in Congress." " ${ }^{2}$ The consent of the state legislature is not necessary to the acquisition of property or to its use by the federal government, "but only to the exclusion of state jurisdiction over the place." 83 In the second place, disposing of the suggestion that Congress ought first to have condemned the submerged lands on which the bridge piers were to rest, he pointed out that since the state's ownership of submerged lands is not absolute but is "an ownership held, not for the purpose of emolument, but for public use, especially the public use of navigation and commerce," ${ }^{84}$ it should be held to follow that "the appropriation of a few square feet of the river bottom to the foundation of a bridge which is to be used for the transportation of an extensive commerce in aid and relief of that afforded by the water-way" ${ }^{85}$ constituted, in effect, no diversion of the state's property from its original public use and hence no taking requiring compensation. ${ }^{86}$

8232 Fed. at 17.

${ }^{83}$ At 18, citing U. S. Const., Art. I, § 8, par. 17. See, in this connection, Chappell v. United States, 160 U. S. 499, 16 Sup. Ct. 397 (1896); United States v. San Francisce Bridge Co., 88 Fed. 891 (N. D. Calif. 1898).

81 At 20. The court's doubt as to whether submerged lands are " $a$ kind of property susceptible of pecuniary compensation" seems unwarranted. See Kerr v. West Shore R. R., 127 N. Y. $269,275,27$ N. E. 833 (1891).

85 At 20.

${ }^{80}$ The power of the United States to condemn foreshore lands for the advancement of powers conferred on the federal government by the Constitution was recognized obiter in an early case, Pollard's Lessee v. Hagan, supra note 16. The court had before it no question of power under the commerce clause but merely a patent from the federal government to lands under water. This patent was held insufficient to support an action of ejectment, but the court said, at 230: "This right of eminent domain over the shores and the soils under the navigable waters, for all municipal purposes, belongs exclusively to the states within which their respective territorial jurisdictions, and they, and they only, have the constitutional power to exercise it. To give to the United States the right to transfer to $\mathfrak{a}$ citizen the title to the shores and the soils under the navigable waters, would be placing in their hands a weapon which might be wielded greatly to the injury of state sovereignty, and deprive the states of the power to exercise a numerous and important class of police powors. But in the hands of the states this power can never be used so as to affect the escercise of any national right of eminent domain or jurisdiction with which the United States have been invested by the Constitution. For, although the territorial limits of Alabama have extended all her sovereign power into the sea, it is there, as on the shore, but municipal power, subject to the constitution of the United States, 'and the laws which shall bo made in pursuance thereof." "[Italics ours]. And its existence was vigorously upheld in the Stockton case, supra note 57, where the court said, at 19: "If it is necessary that the United States government should have an eminent domain still higher than that of the state, in order that it may fully carry out the objects and purposes of the constitution, then it has it. Whatever may be the necessities or conclusions of theoretical law 
This seems sound from a practical viewpoint. If a state does object to a bridge, but is prevented by the Federal Constitution from giving effect to its objection, money damages measured merely by the value of the submerged lands physically taleen for pier purposes are so incapable of compensating for the severe consequential loss caused by the bridge, ${ }^{\text {st }}$ as to justify dispensing with their assessment and payment under the maxim de minimis non curat lex.

Theoretically, too, the quoted passages are sound. Although Mr. Justice Bradley was unable to support his utterances with authorities, nevertheless his words were quoted with at least tacit approval by the Supreme Court in Seranton v. Whecler, ${ }^{23}$ a case which, however, dealt simply with the erection on submerged lands of a pier whose function was to improve navigation and not to support a bridge. In this connection, it is worthy of note that in practically every case in which the Supreme Court has had to define the nature of that federal overlordship, so to speak, to which the state's title to submerged lands is subject, it has seemingly taken conscious care to describe the federal right as a right to aid navigation by freeing it from state-sanctioned

as to eminent domain or anything else, it must be received as a postulate of the constitution that the government of the United States is invested with full and complete power to execute and carry out its purposes. And as one of these purposes is the regulation of conmerce among the several states, and as that involves the needs and ways of intercommunication, it follows that congress may provide for these necessities whether the states co-operate and concur therein or not." And see Cherokee Nation v. Southern Kansas Ry., 135 U. S. 641, 656, 10 Sup. Ct. 965, 971 (1890).

87 The greatest element of loss to the state or its political subdivisions in the typical case is the impaired value for tax purposes of raterfront property upstream from the bridge. The loss is more dircetly felt where, as in Newark v. Central R. R. Co. of New Jersey, st!pra note 8 , the municipality owns such waterfront lands itself and has built docks and warehouses upon them. Even here the loss, under the rule laid down in Miller v. New York, 109 U. S. 385, 392-393, 3 Sup. Ct. 228, 229 (1389) is generally deemed too remote to warrant either damages or injunctive relief. The contrary decisions in Barnes v. Racine, $4 \mathrm{~W}$ is. 454 (1856) and Maswell v. Bay City Bridge Co., 46 Mich. 278, 9 N. W. 410 (1881) are opposed to the weight of authority. See Gilman v. Philadelphia, sapra note 20; Frost v. Washington County R. R., supra note 51; Dover v. Portsmouth Bridge, 17 N. H. 200 (1845) ; Bailey v. Phila., Wil. \& Balt. R. R., 4 Harr. 289 (Del. 1846).

ss 179 U. S. 141, 159-160, 21 Sup. Ct. 48, 55-56 (1900). In two other cases, Willamette Iron Bridge Co. $\mathrm{v}$. Hatch, supra note 45 , and Califorma v. Pacific R. R., 127 U. S. 1, \& Sup. Ct. 1073 (1888), DIr. Justice Bradley, speaking for a unanimous bench, used language of the same tenor as that previously employed by him in the Stockton case. See the comment to this effect in Luxton v. North River Bridge Co., supra note 13 , at 582, 14 Sup. Ct. at 893. Yet none of these cases passed upon the right of uncompensated taking of state-owned submerged lands sanctioned by the Stocliton case. 
obstructions. One of the most recent illustrations is United States v. Holt State Bank, ${ }^{89}$ where the court said: ${ }^{00}$

"It is settled law in this country that lands underlying navigable waters within a State belong to the State in its sovereign capacity and may be used and disposed of as it may elect, subject to the paramount power of Congress to control such waters for the purposes of navigation in commerce among the States and with foreign nations, . . . ."

On the other hand, the federal government could not aid navigation at all if it were not for its power to aid commerce. ${ }^{01}$ The power thus upheld is greater rather than less when traced to its source. Hence, where the taking of state-owned submerged lands is to aid land-borne commerce by the erection of a bridge, the power of Congress is still unchallengeable. Into this particular neck of the vast woods of commerce power jurisprudence, the Supreme Court has not yet entered; but when it does so it is safe to prophesy that the highway of its considered judgment will follow closely the trail which Mr. Justice Bradley blazed in 1887.

\section{CONCLUSION}

Under existing law, where a bridge is to be erected over navigable waters wholly within one state, it is sufficient if the bridge builder secures authorization from the state and has the plans and specifications for the bridge approved by the Secretary of War. There is nothing, however, to prevent the builder procuring in the first instance a special act of Congress. This, by the weight of authority, renders state statutes qualifying the right to build bridges nugatory. If the bridge is over navigable waters not wholly within one state, the state authorities are without jurisdiction and authorization should be secured by special act of Congress. This procedure is contemplated in such cases by the Bridge Act of 1906 . The approval of the plans and specifications by the Secretary of War will usually be insisted upon in the Act. The power of Congress to dispense with state assent to any bridge employed to further interstate commerce is absolute.

89270 U. S. 49,46 Sup. Ct. 197 (1926).

90 At 54, 46 Sup. Ct. at 198. Other observations to the same effect occur in Huse v. Glover, 119 U. S. 543, 548-549, 7 Sup. Ct. 313, 316 (1886) ; Gibson v. United States, supra note 19; United States v. Rio Grande Irrigation Co., 174 U. S. 690, 708, 19 Sup. Ct. 770, 777 (1899); Willink v. United States, 240 U. S. 572, 580, 36 Sup. Ct. 422,424 (1916); Port of Seattle v. Oregon \& W. R. R., supra note 47, at 63, 41 Sup. Ct. at 239; Sanitary District of Chicago v. United States, 266 U. S. 405, 426, 45 Sup. Ct. 176, 178 (1925); Appleby จ. New York, 271 U. S. 364, 401, 46 Sup. Ct. 569, 580 (1926).

91 See cases cited, supra note 20. 